\title{
Candida colonization in neonates admitted to neonatal intensive care unit (NICU) in Mosul
}

\author{
Mazin M. Fawzi ${ }^{a}$, Ahmad S. Abdullah ${ }^{b}$, Eman M. Majeed ${ }^{c}$ \\ ${ }^{a}$ Department of pediatrics, College of Medicine, University of Mosul, ${ }^{b}$ Pediatric specialist, Al Khansaa teaching hospital, ${ }^{\mathrm{c}}$ Msc. \\ Microbiology, Al Khansaa teaching hospital laboratory, Mosul, Iraq. Correspondence: Mazin M. Fawzi. mazin6695@yahoo.com. \\ (Ann Coll Med Mosul 2018; 40 (1): 51-55). \\ Received: 24 ${ }^{\text {th }}$ Sep. 2013; Accepted: $22^{\text {nd }}$ Dec. 2013
}

\section{ABSTRACT}

Background: Candida species are important nosocomial pathogens in the newborns, particularly among the preterms. Colonization of the neonatal skin and gastrointestinal tract is the first step in the pathogenesis of invasive Candidiasis. Colonization of the infant occurs early in life and this is affected by a variety of common practices in the neonatal intensive care unit (NICU).

Objective: To determine colonization of Candida species in neonates admitted to NICU in Mosul city, and to identify the possible risk factors for colonization.

Patients and methods: A case series study was conducted in a Al Khansaa Teaching Hospital in Mosul city between September 2012 to March 2013. Fifty neonates who were admitted for several causes and stayed in the hospital for seven or more days were included in the study. Sterile cotton tipped swabs from oral, rectal and umbilical areas of each neonate were collected within 24 hours of admission, day five, day seven or thereafter when the neonate was discharged from hospital. Swabs were smeared on the surface of plates of Sabourauds glucose agar. Data was analyzed using Students "t" test, Chi-square test and Fisher's exact test wherever necessary.

Results: Candida colonization was seen in $70 \%$ of patients at different sites and times of samples collection. Colonization was more common in males than females. From the colonized neonates, $60 \%$ were full term and $40 \%$ were premature, and $74 \%$ had normal birth weight and $26 \%$ had low birth weight. Acquisition of Candida occurred in $63 \%$ of neonates within the first 24 hrs and by day five $94 \%$ of neonates were colonized. The remaining $6 \%$ were colonized after fifth days of admission. Male sex, normal birth weight and signs of vaginal candidiasis in the mother were found to be significant risk factors for neonatal colonization.

Conclusion: Candida colonization was seen in $70 \%$ of the study sample. Male neonates were colonized more often than females. Male sex, normal birth weight and signs of maternal vaginal candidiasis were significant risk factors for neonatal colonization with Candida.

Keywords: Candida colonization, neonates, intensive care, Mosul.

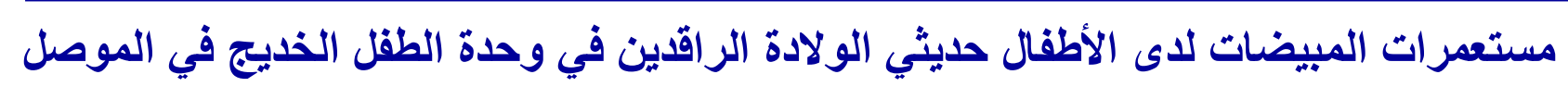

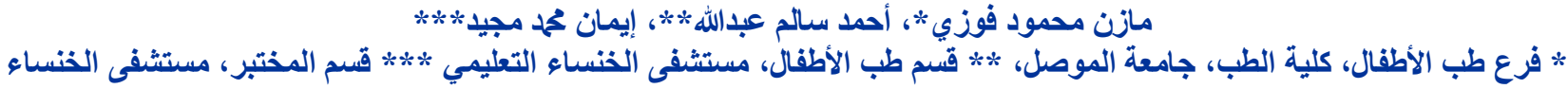

$$
\begin{aligned}
& \text { التعليمي، الموصل، العراق }
\end{aligned}
$$

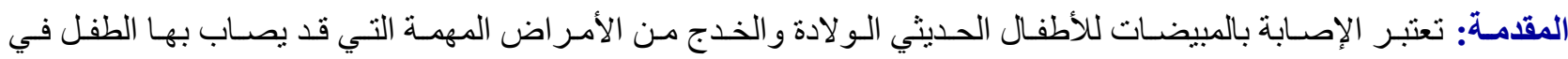

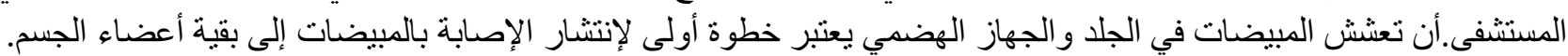

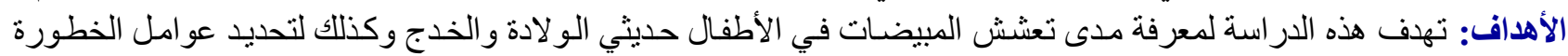




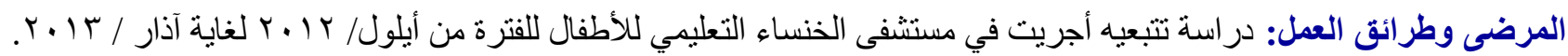

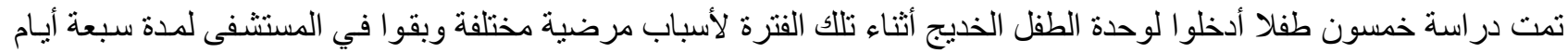

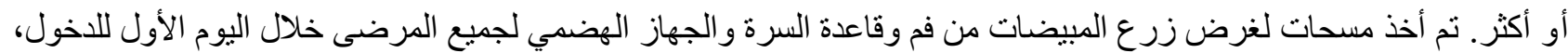

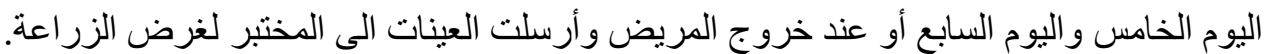

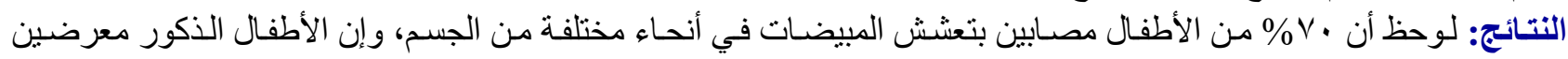

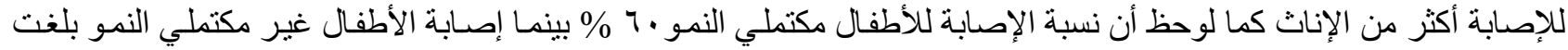

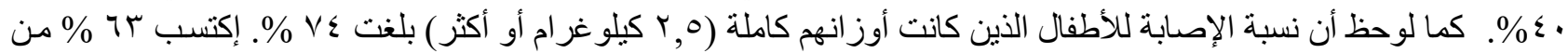

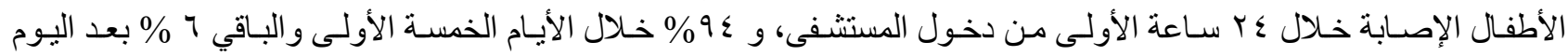

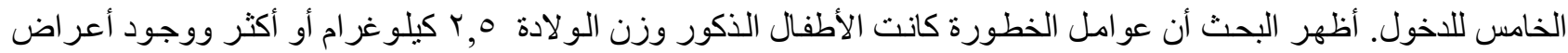

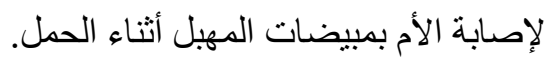

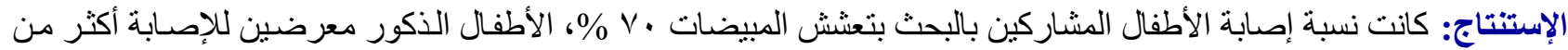

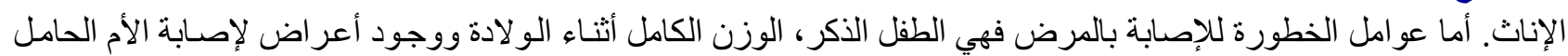

الكلمات المفتاحيه: مستعمر ات المبيضات، أطفال حديثي الو لادة، وحدة العناية المركزة، الموصل.

\section{INTRODUCTION}

C andida species are significant nosocomial microorganism in the neonate, especially in the preterm. The first step in Candida invasion is colonization of the gastrointestinal tract (GIT) and skin of neonates. ${ }^{1}$ Candida albicans is the commonest detected species in colonized or infected neonates. During the last years colonization and infection with other candida species has increased dramatically especially among premature infants. ${ }^{2,3}$ This has been attributed to the use and duration of broad spectrum antibiotics therapy, ${ }^{4}$ technology advancement of life supporting systems, relative immunodeficiency in the neonates, ${ }^{5,6}$ colonization of maternal vagina and Candida ability to live on environmental surfaces. ${ }^{7}$

Infant colonization by candida occurs early in life due to routine daily works in the neonatal intensive care unit (NICU). Neonatal fungal infections are associated with substantial mortality and morbidity. ${ }^{8}$

Risk factors of Candida colonization or infection are preterm neonates who need invasive and aggressive diagnostic and therapeutic procedures, congenital anomalies, prior antibiotic therapy, necrotizing enterocolitis and gastrointestinal tract diseases. Prior colonization is the major risk factor for candida infection. ${ }^{9}$

Most neonatal candidiasis is endogenously acquired through prior colonization of different parts of the neonatal body. Other studies suggested that some outbreaks of candidiasis were caused by nosocomial infection in NICU. ${ }^{10}$

In general, the first step towards severe infection is Candida colonization, which lives as normal flora in the intestine.$^{11-13}$ Actually, Wey et $a l^{14}$ during the 1980s, recognized Candida colonization as an independent risk factor for candidemia. In fact, colonization of multiple sites is an improtant risk factor for invasive fungal infection in severely ill neonates and the density of colonization could be a predictive value for the diagnosis of systemic candidiasis, ${ }^{15-17}$ indeed its difficult to recognize between infection and colonization. ${ }^{18}$ Candida colonization can present in $5-50 \%$ of neonates and an invasive infection can develop in $5-30 \%$ of colonized patients. ${ }^{19,20}$ The death risk in neonates with distinct Candida colonized body sites is similar to that of neonates with proven invasive infection. ${ }^{20}$

Aim of the study:

1- To determine colonization of Candida species in neonates admitted to NICU in Mosul city.

2- To detect the possible colonization risk factors.

\section{PATIENTS AND METHODS}

A case series study was conducted at Al Khansaa Teaching Hospital in Mosul city in the period from September 2012 to March 2013. A total of 50 neonates (premature and full term) who were admitted for several causes and stayed in the 
hospital for 7 or more days were included in the study. All of them were kept in incubators and received antibiotics (ampicillin and aminoglycosides or ampicillin and third generation cephalosporin).

Specimens collection: Swabs from rectal, oral and umbilical areas of each neonate were collected within 24 hours of admission, $5^{\text {th }}, 7^{\text {th }}$ day or after that when the patient was discharged from hospital.

Collection of samples were done by using sterile cotton swabs after moistening them with sterile saline and all samples were processed to the laboratory within 30 minutes of collection. Swabs were smeared on the surface of plates of Sabourauds glucose agar which were incubated for 48 hours at $37 \mathrm{C}^{\circ}$. All samples that yielded yeast colonies were proceeded further for the identification of Candida species and positive results were indicated by positive Germ tube test \&/or API Candida test (Biomieux).

Collection of blood samples from the neonate and vaginal swabs from the mother were not part of the study.

In neonates, information about I) intake of antibiotics, steroids, blood transfusion or exchange, II) type of feeding III) associated disease or anomaly, IV) birth weight, and V) sex, were recorded. And in mothers I) site of delivery, II) gestational age, III) type of delivery, IV) duration of rupture of membrane, V) signs of vaginal candidiasis, and meconium stained liquor were noted and recorded.

Data was analyzed using Students "t" test, Fisher's exact test and Chi-square test wherever necessary.

\section{RESULTS}

The total number of patients included in the study was 50, (28 males and 22 females). Candida colonization was seen in $35(70 \%)$ of the patients at different sites and times of samples collection.

Table 1 showed the characters of colonized neonates. Colonization was detected in $23(65 \%)$ males and 12 (35\%) females with male: female ratio of 1.9:1. From the colonized neonates, 21 $(60 \%)$ were full term and 14 (40\%) were premature. Twenty six (74\%) of the colonized neonates had normal birth weight while $9(26 \%)$ had low birth weight.
Table 2 showed the date and site of colonization. Among the colonized neonates acquisition of Candida occurred in $63 \%$ of them within the first 24 hrs and by day five $94 \%$ of neonates were colonized. The remaining $6 \%$ were colonized after fifth days of admission.

Regarding site of colonization, colonization of one site was seen in $19(54 \%)$ of patients, and in two sites were seen in $16(46 \%)$ of patients. The maximum colonization was in the mouth $(66 \%)$ followed by the rectum (57\%) and the umbilicus $(20 \%)$. However earliest colonization i.e., within 24 hrs was that of the umbilicus $(71 \%)$.

Table 3 showed the risk factors that lead to Candida colonization, it is clear from this table that male sex, normal birth weight and signs of vaginal candidiasis in the mother were found to be significant risk factors. However colonization in neonates was seen more frequently in those with normal vaginal delivery, non-breast milk feeding and delivery at hospital, but the differences were not statistically significant.

Table 1. Characters of colonized neonates.

\begin{tabular}{lc}
\hline \multicolumn{1}{c}{ Patents character } & No= $35(100 \%)$ \\
\hline$q$ & $12(35 \%)$ \\
\hline & $23(65 \%)$ \\
Full term & $21(60 \%)$ \\
premature & $14(40 \%)$ \\
LBW & $9(26 \%)$ \\
NBW & $26(74 \%)$ \\
\hline
\end{tabular}

Table 2. Date and site of colonization.

\begin{tabular}{lcccc}
\hline \multirow{2}{*}{ Colonization } & \multicolumn{3}{c}{ Time } & \multirow{2}{*}{ Total } \\
\cline { 2 - 4 } & $\mathbf{2 4} \mathrm{hr}$ & $\mathbf{5}$ days & $\begin{array}{c}>5 \\
\text { days }\end{array}$ & \\
\cline { 2 - 3 } $\begin{array}{l}\text { Number of } \\
\text { colonization }\end{array}$ & $\begin{array}{c}22 \\
(63 \%)\end{array}$ & $\begin{array}{c}11 \\
(31 \%)\end{array}$ & $2(6 \%)$ & 35 \\
Cumulative & 22 & 33 & 35 & - \\
colonization & $(63 \%)$ & $(94 \%)$ & $(100 \%)$ & - \\
\hline Mouth & 13 & 7 & 3 & 23 \\
Umbilicus & $(57 \%)$ & $(30 \%)$ & $(13 \%)$ & $(66 \%)$ \\
\hline Rectum & 5 & 2 & 0 & 7 \\
\hline
\end{tabular}


Table 3. Risk factors for Candida colonization.

\begin{tabular}{|c|c|c|c|c|}
\hline \multirow[t]{2}{*}{ Factor } & \multicolumn{2}{|c|}{$\begin{array}{l}\text { Candida } \\
\text { positive } \\
\mathrm{n}=35\end{array}$} & \multicolumn{2}{|c|}{$\begin{array}{c}\text { Candida } \\
\text { negative } \\
\mathrm{n}=15\end{array}$} \\
\hline & No. & $\%$ & No. & $\%$ \\
\hline $\begin{array}{l}\text { 1-Gestational age } \\
\text { premature } \\
\text { full term }\end{array}$ & $\begin{array}{l}14 \\
21\end{array}$ & $\begin{array}{l}(40) \\
(60)\end{array}$ & $\begin{array}{l}10 \\
5\end{array}$ & $\begin{array}{l}(66.7) \\
(33.3)\end{array}$ \\
\hline $\begin{array}{l}\text { 2-Birth weight } \\
\geq 2.5 \mathrm{~kg} \\
<2.5 \mathrm{~kg}\end{array}$ & $\begin{array}{l}26 \\
9\end{array}$ & $\begin{array}{r}(74)^{*} \\
(26)\end{array}$ & $\begin{array}{l}6 \\
9\end{array}$ & $\begin{array}{l}(40) \\
(60)\end{array}$ \\
\hline $\begin{array}{l}\text { 3-sex } \\
\text { Male } \\
\text { Female }\end{array}$ & $\begin{array}{c}23 \\
12\end{array}$ & $\begin{array}{c}(65)^{*} \\
(35)\end{array}$ & $\begin{array}{l}5 \\
10\end{array}$ & $\begin{array}{l}(33.4) \\
(66.6)\end{array}$ \\
\hline $\begin{array}{l}\text { 4-Mode of delivery } \\
\text { NVD } \\
\text { CS }\end{array}$ & $\begin{array}{l}19 \\
16\end{array}$ & $\begin{array}{l}(54) \\
(46)\end{array}$ & $\begin{array}{l}13 \\
2\end{array}$ & $\begin{array}{l}(87) \\
(13)\end{array}$ \\
\hline $\begin{array}{l}\text { 5-PROM } \\
\text { Yes } \\
\text { no }\end{array}$ & $\begin{array}{l}10 \\
25\end{array}$ & $\begin{array}{l}(29) \\
(71)\end{array}$ & $\begin{array}{l}5 \\
10\end{array}$ & $\begin{array}{l}(33.4) \\
(66.4)\end{array}$ \\
\hline $\begin{array}{l}\text { 6-Use of steroid } \\
\text { Yes } \\
\text { no }\end{array}$ & $\begin{array}{l}5 \\
30\end{array}$ & $\begin{array}{l}(15) \\
(85)\end{array}$ & $\begin{array}{l}3 \\
12\end{array}$ & $\begin{array}{l}(20) \\
(80)\end{array}$ \\
\hline $\begin{array}{l}\text { 7-Meconium aspiration } \\
\text { Yes } \\
\text { no }\end{array}$ & $\begin{array}{l}14 \\
21\end{array}$ & $\begin{array}{l}(40) \\
(60)\end{array}$ & $\begin{array}{l}4 \\
11\end{array}$ & $\begin{array}{l}\text { (27) } \\
\text { (73) }\end{array}$ \\
\hline $\begin{array}{l}\text { 8-Signs of vaginal } \\
\text { candidiasis } \\
\text { Yes } \\
\text { no }\end{array}$ & $\begin{array}{l}24 \\
11\end{array}$ & $\begin{array}{c}(69)^{*} \\
(31)\end{array}$ & $\begin{array}{c}14 \\
1\end{array}$ & $\begin{array}{r}(93.4) \\
(6.6)\end{array}$ \\
\hline $\begin{array}{l}\text { 9-Mode of feeding } \\
\text { Breast } \\
\text { Others }\end{array}$ & $\begin{array}{l}7 \\
28\end{array}$ & $\begin{array}{l}(20) \\
(80)\end{array}$ & $\begin{array}{l}7 \\
5\end{array}$ & $\begin{array}{l}(47) \\
(53)\end{array}$ \\
\hline $\begin{array}{l}\text { 10-Place of delivery } \\
\text { Home } \\
\text { Hospital }\end{array}$ & $\begin{array}{l}8 \\
27\end{array}$ & $\begin{array}{l}(22) \\
(78)\end{array}$ & $\begin{array}{l}3 \\
12\end{array}$ & $\begin{array}{l}(20) \\
(80)\end{array}$ \\
\hline $\begin{array}{l}\text { 11-Blood or exchange } \\
\text { transfusion } \\
\text { Yes } \\
\text { No }\end{array}$ & $\begin{array}{l}8 \\
27\end{array}$ & $\begin{array}{l}(23) \\
(77)\end{array}$ & $\begin{array}{l}3 \\
12\end{array}$ & $\begin{array}{l}\text { (20) } \\
\text { (80) }\end{array}$ \\
\hline $\begin{array}{l}\text { 12-Congenital } \\
\text { anomalies } \\
\text { Yes } \\
\text { No }\end{array}$ & $\begin{array}{l}12 \\
23\end{array}$ & $\begin{array}{l}(34) \\
(66)\end{array}$ & $\begin{array}{l}3 \\
12\end{array}$ & $\begin{array}{l}\text { (20) } \\
\text { (80) }\end{array}$ \\
\hline
\end{tabular}

\section{DISCUSSION}

Disseminated candidiasis is an significant cause of neonatal morbidity and mortality and candida colonization is the early step in the pathogenesis of invasive candidiasis. ${ }^{1}$

Neonatal colonization by Candida was $70 \%$ in this study, and this is nearly similar to that in Virginia $(60 \%)^{21}$ but higher than that reported from India $(34 \%)^{1}$ and Italy (18\%). ${ }^{22}$ This variation may be due to difference in intensity of routine antifungal antiseptic measures and difference in the environments.
Colonization of male neonates was more than female in this study, and this is in agreement with a study done in India. ${ }^{1}$ Colonization of full term and normal birth weight neonates were more frequent than premature and low birth weight babies in our study and this is different from other studies done in India ${ }^{1}$ and North Carolina, ${ }^{23}$ which showed no statistical difference between prematurity and birth weight. And this difference may be due to small sample size in our study.

It is noted that neonatal candida colonization occurs during the first few hours of life. ${ }^{2,}{ }^{24}$ In the present study colonization was recognized with in the first 24 hours of admission in $63 \%$ of cases.

Oral $(66 \%)$ and rectal colonization (57\%) were the commonest sites and this is comparable to other studies. ${ }^{1,25}$ Colonization of GIT occurs predominantly during the first week of life, ${ }^{2,26}$ and it can serve as a reservoir from where the Candida can spread and this may be due to poor local colonization resistance particularly if there is a breach in mucosal lining. ${ }^{27}$

The significant risk factors observed in our study were signs of vaginal candidiasis in the mothers, male sex and normal birth weight. The frequency of colonization in neonates was higher in those who were delivered normally through vaginal canal than those delivered by Cesarean intervention and the fact that earliest colonization was that of the oral mucosa (probably colonization during vaginal delivery) signifying that mothers with vaginal candidiasis are important source of neonatal candidiasis. ${ }^{1}$ Male sex was a significant risk factor in the present study and which is similar to that reported from India. ${ }^{1}$ In regard to normal birth weight as a risk factor, found in this study, others did not report similar result. ${ }^{1,28}$ They showed that low birth weight is a risk factor for neonatal colonization which may be attributed to small sample size in our study.

\section{CONCLUSION}

Candida colonization was seen in $70 \%$ of the studied neonates. Male neonates were colonized more often than females. Male sex, normal birth weight and signs of maternal vaginal candidiasis were significant risk factors for neonatal colonization with Candida. 


\section{RECOMMENDATIONS}

1- Monitoring of Candida colonization in hospitalized neonates is an important step to prevent disseminated infection.

2- Over use of steroid and antibiotics, should be avoided.

3- Screening of all pregnant women for the presence of Candida, irrespective of symptoms and treatment of them, is important to decrease colonization and prevent infection of the neonates.

\section{REFERENCES}

1. Mendiratta DK, Rawat V, Thamke D. Candida colonization in preterm baby admitted to neonatal intensive care unit in the rural setting. Indian $\mathrm{J}$ of medical microbiology 2006; 24(4):263-267.

2. Sharp AM, Odds FC, Evans EG. Candida strains from neonates in a special care baby unit. Arch Dis Child 1992; 67: 48-52. [PUBMED]

3. Singh K, Chakrabarti A, Narang A, Gopalan S. Yeast colonization and fungemia in preterm neonates in tertiary care centre. Indian J Med Res 1999; 110: 169-73.

4. Charles PE, Dalle F, Aube H, Doise JM, Quenot JP, Aho LS, et al. Candida spp. colonization significance in critically ill medical patients: a prospective study. Intensive Care Med. 2005 Mar; 31(3):393-400.

5. Phelps M, Ayliffe GA, Babb JR. An outbreak of candidiasis in a special care baby unit: The use of a resistogram typing method. J Hosp Infect 1986; 7: 1320.

6. Burnie JP, Odds FC, Lee W, Webster C, Williams JD. Outbreak of systemic Candida albicans in intensive care unit caused by cross infection. BMJ 1985; 290: 746-748.

7. Pfaller MA. Epidemiology of candidiasis. J Hosp Infect 1995; 30: 329-338.

8. Kaguelidou F, Pandolfini C, Manzoni P, Choonara I, Bonati M, Jacqz-Aigrain E. European survey on the use of prophylactic fluconazole in neonatal intensive care units. Eur J Pediatrics. 2012 Mar; 171(3):439-445.

9. Klempp-Selb B. Rimek D.; Kappe R. Karyotiping of Candida albicans and Candida glabrata from patients with Candida sepsis. Mycoses 2000; 43:159-163.

10. Singhi, S.; Rao, D.S, Chakrabarti, A. Candida colonization and candidemia in a pediatric intensive care unit. Pediatr. Crit. Care Med. 2008; 9: 91-95.

11. Ruping M.J, Vehreschild J, Cornely O.A. Patients at high risk of invasive fungal infection: when and how to treat. Drugs 2008; 68: 1941-1962.

12. Wey S.B, Mori M, Pfaller M.A, Woolson R.F, Wenzel R.P. Risk factors for hospitalacquired candidemia. A matched case-control study. Arch. Int. Med. 1989; 149: 2349-2353.

13. Agvald-Ohman, C, Klingspor, L, Hjelmqvist, $H$, Edlund, C. Invasive candidiasis in long-term patients at a multidisciplinary intensive care unit: Candida colonization index, risk factors, treatment and outcome. Scand. J. Infect. Dis. 2008; 40:145-153.

14. Almirante B, Rodríguez D, Park B.J, Cuenca-Estrella M, Planes, A.M, Almela M, et al. Epidemiology and predictors of mortality in cases of Candida blood stream infection: Results from population-based surveillance, Barcelona, Spain, from 2002 to 2003. J. Clin. Microbial. 2005; 43: 1829-1835.

15. Charles P.E, Dalle F, Aube H, Doise J.M, Quenot J.P, Aho L.S. Candida spp. colonization significance in critically ill medical patients: A prospective study. Intensive Care Med. 2005; 31: 393-400.

16. Paphitou N.I, Ostrosky-Zeichner L, Rex J.H. Rules for identifying patients at increased risk for candidal infections in the surgical intensive care unit: Approach to developing practical criteria for systematic use in antifungal prophylaxis trials. Med. Mycol. 2005; 43: 235243.

17. Petri M.G, Konig J, Moecke H.P. Epidemiology of invasive mycosis in ICU patients: A prospective multicenter study in 435 non-neutropenic patients. Intensive Care Med. 1997; 23:317-325.

18. Slotman G, Shapiro E, Moffa S. Fungal sepsis: multisite colonization versus fungemia. Am. Surg. 1994; 60:107-113.

19. Heljic S, Hukic M, Dzinovic A, BabicM, Djozic M. 173 Fungal Colonization of Newborn in Neonatal Intensive Care Unit: A Prospective Study. Pediatric Research 2005; 58: 384-384.

20. Shireen $Y$ Issa, Eman F Badran, Kamal F Akl, Asem A Shehabi1. Epidemiological characteristics of Candida species colonizing oral and rectal sites of Jordanian Infants. BMC Pediatrics 2011, 11:79.

21. David K, Boyle R, Hazen K. Fluconazol prophylaxis against fungal colonization and infection in preterm infants. Engl J Med. 2001; 345(23):1960-1966.

22. Paolo Manzoni $P$, Ilaria $S$, Hubert $M$. et al, Bovine Lactoferrin Prevents Invasive Fungal Infections in Very Low Birth Weight Infants: A Randomized Controlled Trial. Pediatrics 2012; 129(1):116.

23. Richard A, Randall G, Fisher Daniel K, Benjamin Jr, Kelly Ross, Ross E. When to Suspect Fungal Infection in Neonates: A Clinical Comparison of Bacteremia Candida albicans and Candida parapsilosis Fungemia With Coagulase-Negative Staphylococcal. Pediatrics 2000; 106(4):712-718.

24. Waggoner-Fountain LA, Walker MW, Hollis RJ, Pfaller MA, Ferguson JE 2nd, Wenzel RP, et al. Vertical and horizontal transmission of uniqe Candida species to premature newborns. Clin Infect Dis 1996; 22: 803-8.

25. Gagneur A, Sizun J, Vernotee E, de Parscau L, Quinio D, Le Flohic AM, et al. Low rate of Candida parapsilosis related colonization and infection in hospitalized preterm neonates: A one year prospective study. J Hosp Infect 2001; 48: 193-7.

26. Baley JE, Kliegman RM, Boxerbaum B, Fanarof AA. Fungal colonization in the very low birth weight infant. Pediatrics 1986; 78: 225-32.

27. Rippon JW. Candidiasis and the pathogenic yeasts.Medical Mycology. WB Saunders: Philadelphia; 1988. p. 532-81.

28. Eugene Leibovitz. Strategies for the Prevention of Neonatal Candidiasis. Pediatrics and Neonatology 2012; 53: 83-89. 